\title{
An Investigation of Entrepreneurial Intention amongst Arab University Students
}

\author{
Walid Saleh ${ }^{1} \&$ Loay Salhieh ${ }^{2}$ \\ ${ }^{1}$ Corporate Finance at the Arab Open University, Jordan \\ ${ }^{2}$ School of Management and Logistic Science, German Jordanian University, Jordan \\ Correspondence: Walid Saleh, Corporate Finance at the Arab Open University, Jordan. E-mail: \\ w_saleh@aou.edu.jo
}

Received: June 30, 2014

Accepted: October 8, 2014

Online Published: November 22, 2014

doi:10.5539/ijbm.v9n12p197

URL: http://dx.doi.org/10.5539/ijbm.v9n12p197

\begin{abstract}
This study has proposed a framework to pinpoint factors that could influence the intention to become an entrepreneur among university students from four different Middle East countries. The proposed framework has integrated different explanatory factors that have been used within different approaches into one framework, and assess their relative importance to influence entrepreneurial intentions. Also, the framework was tested on a large diversified multi-country sample from four Middle East countries (Jordan, Lebanon, Egypt, and Oman).The findings stress the role that a university could play at motivating its students to be entrepreneurial and the governmental role in creating a perceived climate that encourages entrepreneurship.
\end{abstract}

Keywords: entrepreneurship, SMEs, economic growth, entrepreneurial economy

\section{Introduction}

Scholars and researchers have pinpointed that entrepreneurship do impact the economic growth and development of a country in general (Ma'rio et al., 2010) and specifically in higher income countries (Nabi \& Liña'n, 2011). The economic influence of entrepreneurship is highlighted by what is called the "entrepreneurial economy" (Thurik, 2009). Many countries have embraced entrepreneurial activities as a primary stream of renovating their economy, a recipe to cope with unemployment problems, and promoted as an enabler of economic progress and job creation in most developing countries. So, the economic function of entrepreneurs is being considered as a development agent (Lin a'n, Rodriguez-cohard, \& Rueda-cantuche, 2005). Consequently, entrepreneurship has captured the attention of both scholars and policy makers during the last decades. Their attention falls on the question of why some people choose an entrepreneurial career and others do not.

Previous studies have focused on exploring and investigating a wide array of possible enablers of entrepreneurial activity. The Global Entrepreneurship Monitor (Reynolds et al., 2001) has emphasized that individual's possessing limited education are less enthusiastic to participate in entrepreneurial activities (Turk \& Selcuk, 2009). Therefore, getting an adequate and a proper education may encourage entrepreneurial intention of an individual. Consequently, universities play a major role as a pool of potential sources of future entrepreneurs and in the process affect the intention aspects to be entrepreneurs (Gibb, 1996; Etzkowitz et al., 2000; Johannisson et al., 1998). Many universities in the Middle East countries have recognized this role and established incubators and entrepreneurship centers on campus in order to motivate students to be future potential entrepreneurs. There is a paramount increasing attention on graduate entrepreneurship in developed countries as it appears that entrepreneurial intentions are a function of a "regional dimension". But research on entrepreneurial intention and education in developing countries is still lacking behind. It is of paramount important to investigate, digest, and understand the perceptions of students at higher education level regarding factors that influence their intention to be entrepreneurial (Stephen et al., 2005; Vaillant \& Lafuente, 2007). Based on these premises, our central research questions are: what are the entrepreneurial intentions on university students in different middle-east countries? What are the perceptual enablers that most contribute to entrepreneurial intentions? The purpose of the current study is to explore and analyze factors that could influence the entrepreneurial intention of university students in a targeted sample of Middle East countries (Jordan, Lebanon, Egypt, \& Oman).

This study adopts the definition of entrepreneurial intention as a conscious awareness and conviction by an 
individual that they intend to set up a new business venture and plan to do so in the future (Thompson, 2009, Nabi, Holden \& Walmsleg, 2010). So, a framework that mainly focuses on the impact of some contextual and cognitive factors is proposed and empirically tested. Therefore, this study seeks to make several conceptual and empirical contributions. Mainly, the study contributes by integrating several enablers from intention literature into a comprehensive framework. Further, fresh insights are provided with regard to a hand-collected data set involving a sample of 1000 university students. Also, this paper contributes to our understanding of entrepreneurial behavior by showing that conviction is an important antecedent of entrepreneurial intention. The researchers believe that the results of this study may have significant implications for policy makers and university administrators. The study is structured as follows. We first explore the entrepreneurship intention literature, and introduce the proposed framework. The methodology section describes data collection, the sample, and the results of the study. Limitations, future research, implications, and conclusion are highlighted in section four.

\section{Exploring the Entrepreneurship Intention Literature}

Theories that predicted entrepreneurial intentions such as theory of the entrepreneurial event (Shapora \& Sokol, 1982), the model of implementing entrepreneurial ideas (Bird, 1988), the maximization of the expected utility model (Douglas \& Shepherd, 2002), and the theory of planned behavior (Ajzen, 1991) has been shown to consistently predict entrepreneurial intentions. Iakovleva, Kolvereid, and Stephan (2011) have provided a reliable test of consistency of the Theory of Planned Behavior in explaining entrepreneurial intention across countries. Along the same stream of research of "planned behavior", the theory of the entrepreneurial event (Shapero \& Sokol, 1982) which considers the birth of a firm as the result of interactions among contextual factors and consequently influence the individual's perceptions. Based on the aforementioned theories, some scholars have explored contextual and cognitive factors that might influence entrepreneurship intention among university students (Turker \& Selcuk, 2009). Entrepreneurial spirits of university students in Hong Kong and Singapore were investigated and compared based on cognitive factors such as the role of personality characteristics and motivational factors (Ang \& Hong, 2000). Also, Wang and Wong (2004) pinpointed that gender, family business experience and education levels are important factors in explaining entrepreneurial intention among university students in Singapore. Also, there is a particular interest in exploring entrepreneurial intention in developing countries. Gird and Bagraim (2008), studied students from South Africa; Jones et al. (2008), studied Polish students; and $\mathrm{Wu}$ and $\mathrm{Wu}$ (2008), studied Chinese students. Also, scholars have explored entrepreneurial intentions across different countries (Liña'n \& Chen, 2009; Engle et al., 2010; Moriano et al., 2011). The approaches of these studies follow the mainstream of the entrepreneurship literature as they focused on personality characteristics, impact of contextual factors, and others have incorporated both. This study has followed the same mainstream in proposing the study framework to investigate the factors that could influence the intention among university students across different Middle East countries in a more comprehensive way.

\section{Research Hypotheses}

In the light of previous studies, this study proposes a framework of the determinants of entrepreneurial intention among Arab students. The purpose is not so much to introduce entirely new insights, but the intended contribution is two folds. First, integrate different explanatory factors that have been used within different approaches into one framework, and assess their relative importance to influence entrepreneurial intentions. Second fold, is to test this framework on a large diversified multi-country sample from four Middle East countries (Jordan, Lebanon, Egypt, and Oman). The proposed framework that has guided the empirical analyses to follow is depicted in Figure-1. The rational behind the relationships suggested by the framework according to previous studies will be discussed below.

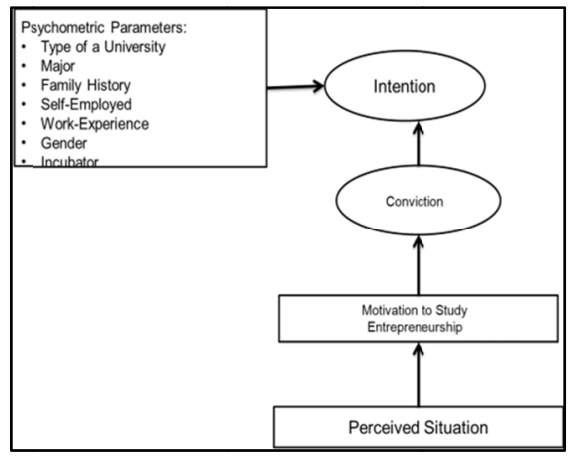

Figure 1. Proposed framework 
Conviction: The framework proposes that a major determinant of intention is the individual's conviction to start a new firm is the best choice as a career. This variable has been highlighted in previous studies (Boyd and Vozikis, 1994; Krueger, 1994). But, the proposed framework suggests that this variable is formed and influenced by another variable (motivation to study entrepreneurship). The responses to the six items were obtained on a 5-point scale with 1 being "very unlikely" and 5 being "very likely" as shown in Appendix A. Based on the above discussion, it is hypothesized that:

H1. Entrepreneurial intention of university students relates with conviction to start a business.

Psychometric variables: This study as others wants to investigate the effect of psychometric variables on intention (Iakovleva, Kolvereid, \& Stephan, 2011). The suggested variables are family history of being entrepreneurs, country, and type of a university (state or private), gender, work experience and self employed as shown in Appendix-A. Therefore, the paper hypothesized that:

H2: Psychometric variables (such as family history of being entrepreneurs, country, and type of a university; state or private, gender, work experience and self employed) have effects on Entrepreneurial intention of university students.

Motivation to study entrepreneurship: Hytti et al. (2010) have pointed in their study that motivation is a condition driven by motives and drives the individual to act in a certain way. It can encourage or discourage the behavior. Cognitive theories and behaviorist emphasize the impact of intrinsic and extrinsic factors in stimulating motivation (Good \& Brophy, 1990). This study suggests that in order to reach the conviction state to start a new business, motivation regardless from intrinsic or extrinsic factors must exist (Helm-Stevens \& Griego, 2009) prior to the conviction state. The extrinsic factor that could contribute to the motivation variable is perceived situation favorably or unfavorably. The responses to the six items were obtained on a 5-point scale with 1 being "strongly disagree" and 5 being "strongly agree" as shown in Appendix-A. Based on this proposition, it is hypothesized that:

H3: Students who are motivated to study entrepreneurship studies are more likely to have higher convictions to start their own business.

Perceived Situation: The significance of situational factors for entrepreneurial decision is highlighted and investigated in the literature (Storey, 1994; Bird, 1993; Reynolds, 1991). Many scholars have indicated that understanding the relevant contextual factors can provide insights into the nature and dimensions of entrepreneurial climate in a country (Devonish et al., 2010). This study proposes that perceived situation will affect and influence the motivation to study entrepreneurship and consequently form the conviction to start a new business. This perception by an individual is much more relevant to the conviction to start a business as it motivates or demotivates an individual. Also, this perception is different from one person to the other given the same situation. This study investigates several contextual factors as perceived by an individual such as (Lu"thje \& Franke, 2003; Turker \& Selcuk, 2009; Schwars et al., 2009):

- Society: how society looks at entrepreneurs.

- Government policy: support of entrepreneurs.

- Finance: difficulty of accessing capital to fund new business start-ups.

- Market: opportunities to start a new business in a country.

- University education: It is believed that university education could contribute to increasing the number and quality of entrepreneurs in a country (Matlay, 2006). Recent results show that a university education and support in entrepreneurship activities (such as incubator on campus) has a positive effect on the desirability and feasibility of starting a new business (Peterman \& Kennedy, 2003). Thus, the paper hypothesized that:

H4: Students who have positive perception of the external environment (perceived situation) are more likely to be motivated to enlist or participate in studying entrepreneurship studies.

The responses to the perceived situation constructs were obtained on a 5-point scale with 1 being "strongly disagree" and 5 being "strongly agree" as shown in Appendix A.

Intention: The significance of intention as a predictor of planned behavior (such as the decision to start a new company) has been emphasized in literature (Krueger, Reilly, \& Carsrud, 2000). So, this study considers this variable as a dependent measure in the proposed framework. The respondents were asked to indicate the extent to which they have thought, intended, desired, faced with the opportunity, or planned to open a business. The responses to the five items were obtained on a 5-point scale with 1 being "very unlikely" and 5 being "very likely" as shown in Appendix A. Therefore, the paper hypothesized that: 
H5. The determinants of Entrepreneurial intention are the same between students in selected Arab countries.

\section{Methodology}

\subsection{Data Collection Methodology}

This study aims to explore and analyze factors that could influence the entrepreneurial intention of university students. The study used both quantitative and qualitative methods for collecting data. The time span for collecting these data was from March, 2012 to September, 2012. The data was gathered from the research team through traditional and electronically questionnaires. The quantitative approach was based on a survey questionnaire broken down into five sections. This questionnaire was reviewed by experts in the field. Furthermore, the researchers were deployed over a one-month period to interview experts in the field. In order to prepare the questionnaire, we conducted an in depth review of related literature, several interviews with faculty members, and other experts (entrepreneurship center management). Our selection of items was based on literature review (Intention, Conviction, Perceived Situation, and Motivation to study entrepreneurship) and an important ratings (family history of being entrepreneurs, country, type of a university (state or private), sex, work experience and self employed) provided by literature review, experts and faculty members. The questionnaire was first designed in English and then carefully translated into Arabic by the research team using the translation-back-translation technique (Hambleton, 1994). Both languages were included in the distributed questionnaire (Appendix-A).

\subsection{Sampling}

The sample size for this study was set at 1000 students. However, we drew stratified targeted samples in all universities and received a highly satisfactory overall response rate approximate to 85 percent. In constructing the sample for this study, the data was complied from several departments at different universities in different countries physically and electronically. To be more specific, four initial requirements were taken under consideration and used to create the sample distribution (Table 1). The first consideration would involve state and private universities in each country. The second would involve universities that own business incubators and that did not own. The third would involve students from different departments; business, IT, and engineering. The last consideration would consist of students from the third and fourth-level.

Table 1. Sample distribution

\begin{tabular}{lll}
\hline Category & Sub-Category & Frequency \\
\hline \multirow{3}{*}{ Country } & Egypt & $27 \%$ \\
& Lebanon & $27 \%$ \\
& Oman & $35 \%$ \\
\multirow{2}{*}{ Type of University } & Jordan & $11 \%$ \\
\hline \multirow{3}{*}{ Major } & State & $43.2 \%$ \\
& Private & $56.8 \%$ \\
\hline
\end{tabular}

\subsection{Findings and Discussion}

The paper first applies the descriptive statistics to explore the general profile of the respondents. Table-2 presents the average and standard deviation performance score for each construct and sub-construct. The constructs measures were self reports from respondents and reflect their perceptions of the proposed constructs. On average, it appears that respondents had a moderate intention, conviction to be entrepreneurial, and motivated to study Entrepreneurship. But, their perception of the market condition, governmental regulations and policies, and their university education were moderately low even though the financial sources and the society encouragement were moderate. 
Table 2. Descriptive statistics

\begin{tabular}{lllll}
\hline Construct Measure & Sub-Construct Measure & \# of Items & Mean & SD \\
\hline Intention & & 5 & 3.3016 & 0.8059 \\
Conviction & & 5 & 3.7298 & 0.8804 \\
\hline Overall Perceived Situation & & 29 & 2.7909 & 0.5649 \\
& Market & 4 & 2.9387 & 0.5719 \\
& Finance & 2 & 3.1054 & 0.8714 \\
& Government Policy & 5 & 2.7624 & 0.5959 \\
& Society & 2 & 3.1568 & 0.8278 \\
& University Education & 16 & 2.6702 & 0.7920 \\
\hline Motivation to study & & 6 & 3.6300 & 0.8402 \\
Entrepreneurship & & & & \\
\hline
\end{tabular}

Next, this study examines the validity and reliability analysis. As a first step to validate the appropriateness of the proposed framework, a confirmatory factor analysis (CFA) was used to confirm whether the items actually belong to the factors for which they are theoretically designed. The CFA was performed by carrying out path analysis using structural equation modeling. The hypothesized measurement model was tested for model fit. The path model showed an acceptable fit $((\mathrm{x} 2 / \mathrm{df}=10.993 \mathrm{p}<0.005$, RMSEA $=0.073, \mathrm{CFI}=0.993$, GFI $=0.994$, TLI $=$ 0.978). Therefore, it can be concluded that the proposed constructs that affect intention can be generalized into four major dimensions (conviction, motivation, perceived situation, and psychometric parameters). The second step in validating the framework is to determine the relative influence of the independent variables, a hierarchical stepwise multiple regression was run on intention to start a business, using the conviction construct's items as potential predictors, while using the demographics parameters as control variables (country, type of a university, gender, work experience, self-employed, family owns a business, major, university owns an incubator). Stepwise regression is the combination of forward selection and backward elimination methods. The purpose of the stepwise regression method is to find a meaningful subset of independent input variables which predict the dependent variable correctly. In every iteration, the terms that must be included or excluded in the model are reassessed using their partial $\mathrm{F}$ statistics at every iteration. The best subset method finds the possible $\mathrm{n}$ best subsets of $\mathrm{i}$ terms $(\mathrm{i}=1$, $2, \ldots, \mathrm{k})$ of the regression model. For each subset, it calculates the coefficient of determination $-\mathrm{R}^{2}$ and adjusted $\mathrm{R}^{2}$ values, so that we can choose a subset that has a good balance of high $\mathrm{R}^{2}$ adj and small number of terms. $\mathrm{R}^{2}$ provides a measure of how well outputs are likely to be predicted by the regression model. The bigger the value, the better fit the model. However, only considering $\mathrm{R}^{2}$ is not adequate to evaluate a regression function because the $\mathrm{R}^{2}$ value always increases with the addition of a new input variable to the function, even if it is not significant. If the $\mathrm{R}^{2}$ adj value is significantly lower than $\mathrm{R}^{2}$, it normally means that one or more explanatory variables are missing. Therefore, usually $\mathrm{R}^{2}$ adj value is used for evaluating a regression function and it is preferable for $\mathrm{R}^{2}$ adj to be large and close enough to the $\mathrm{R}^{2}$.

For the combined data, a total of 57.69 percent of the variance was explained as shown in Table-3. Based on this analysis, the following psychometric parameters were deleted (type of a university, Gender, Work Experience, Major, and a University owns an Incubator) from further analysis. Also, the following items that represent the Conviction construct were deleted (Con-2) and the average of the construct were recalculated for further analysis. In addition, the authors use Cronbach's Alpha to examine internal consistency which is mainly used to assess the reliability of the proposed constructs (Nunnally, 1978). If the value of Cronbach's Alpha is greater than 0.6, the reliability of the responding survey's results proves to be acceptable. 
Table 3. Stepwise analysis of psychometric parameters and conviction items upon intention $(\mathrm{R}=$ removed $)$

\begin{tabular}{|c|c|c|c|c|c|}
\hline \multicolumn{6}{|c|}{ Alpha-to-Enter: 0.05 Alpha-to-Remove: 0.05} \\
\hline & & Step-1 & Step-3 & Step-5 & Step-7 \\
\hline Constant & & 1.226 & 1.233 & 1.201 & 1.173 \\
\hline \multirow[t]{2}{*}{ Country } & T-value & 3.00 & 3.01 & 3.22 & 3.76 \\
\hline & P-value & 0.003 & 0.003 & 0.001 & 0.000 \\
\hline \multirow[t]{2}{*}{ Type of university } & T-value & -1.89 & -1.84 & -0.074 & $\mathrm{R}$ \\
\hline & P-value & 0.060 & 0.066 & 0.054 & $\mathrm{R}$ \\
\hline \multirow[t]{2}{*}{ Gender } & T-value & 0.30 & $\mathrm{R}$ & $\mathrm{R}$ & $\mathrm{R}$ \\
\hline & P-value & 0.767 & $\mathrm{R}$ & $\mathrm{R}$ & $\mathrm{R}$ \\
\hline \multirow[t]{2}{*}{ Work Experience } & T-value & -3.48 & -3.52 & -4.23 & -4.86 \\
\hline & P-value & 0.001 & 0.000 & 0.000 & 0.000 \\
\hline \multirow[t]{2}{*}{ Self-Employed } & T-value & -1.31 & -1.25 & $\mathrm{R}$ & $\mathrm{R}$ \\
\hline & P-value & 0.192 & 0.212 & $\mathrm{R}$ & $\mathrm{R}$ \\
\hline \multirow[t]{2}{*}{ Family Owns a Business } & T-value & -2.31 & -2.30 & -2.34 & -2.21 \\
\hline & P-value & 0.021 & 0.022 & 0.020 & 0.027 \\
\hline \multirow[t]{2}{*}{ Major } & T-value & 1.89 & 1.85 & 1.88 & $\mathrm{R}$ \\
\hline & P-value & 0.060 & 0.065 & 0.060 & $\mathrm{R}$ \\
\hline \multirow[t]{2}{*}{ University Own An Incubator } & T-value & 0.85 & 0.91 & $\mathrm{R}$ & $\mathrm{R}$ \\
\hline & P-value & 0.397 & 0.362 & $\mathrm{R}$ & $\mathrm{R}$ \\
\hline \multicolumn{6}{|l|}{ Conviction Construct Items } \\
\hline \multirow[t]{2}{*}{ Con-1 } & T-value & 8.57 & 8.65 & 8.65 & 8.70 \\
\hline & P-value & 0.000 & 0.000 & 0.000 & 0.000 \\
\hline \multirow[t]{2}{*}{ Con-2 } & T-value & 0.53 & $\mathrm{R}$ & $\mathrm{R}$ & $\mathrm{R}$ \\
\hline & P-value & 0.593 & $\mathrm{R}$ & $\mathrm{R}$ & $\mathrm{R}$ \\
\hline \multirow[t]{2}{*}{ Con-3 } & T-value & 9.28 & 10.30 & 10.40 & 10.49 \\
\hline & P-value & 0.000 & 0.000 & 0.000 & 0.000 \\
\hline \multirow[t]{2}{*}{ Con-4 } & T-value & 5.78 & 5.79 & 5.80 & 5.86 \\
\hline & P-value & 0.000 & 0.000 & 0.000 & 0.000 \\
\hline \multirow[t]{2}{*}{ Con-5 } & T-value & 6.64 & 6.76 & 6.75 & 6.59 \\
\hline & P-value & 0.000 & 0.000 & 0.000 & 0.000 \\
\hline \multicolumn{6}{|l|}{ Model-Fit } \\
\hline & $\mathrm{R}-\mathrm{Sq}$ & 58.50 & 58.48 & 58.37 & 58.03 \\
\hline & R-Sq (adj) & 57.86 & 57.94 & 57.92 & 57.69 \\
\hline
\end{tabular}

Note. For extra explanations of Con-1 to Con-5, see Appendix-A.

After aforementioned reliability and validity analyses, this study employs Multivariable Regression analysis to examine the proposed research hypotheses. The authors divide the research model into three sections for detailed discussion. The first section is developed to examine the effects of essential key factors on Intention which are the Conviction construct and the remaining psychometric parameters (Country, Work Experience, self-employed). The second section is developed to examine the effects of the "Motivation to Study Entrepreneurship" construct on the "Conviction" construct. Finally, the third section examines the effects of the "Perceived Situation" construct on the "Motivation to Study Entrepreneurship" construct.

From the first section, which is shown from Table-4, the psychometric parameters (country, Work experience, self-employed) do a significant influence on the "Intention" construct (Hypothesis 2). Also, the "Conviction" construct is significantly important in predicting the "Intention" construct (Hypothesis 1). The results from Table-4 show that the proposed relations with the "Intention" construct is valid and was able to explain $56.7 \%$ of the variability of the construct, and all independent variables are significantly important. 
Table 4. Multivariable regression analysis to predict intention

\begin{tabular}{|c|c|c|c|c|}
\hline Predictor Variable & $\begin{array}{l}\text { Standard } \\
(\mathrm{SE})\end{array}$ & Coefficient & t-value & p-value \\
\hline Country & 0.01521 & & 3.10 & 0.002 \\
\hline Work Experience & 0.05927 & & -2.66 & 0.008 \\
\hline Self-employed & 0.03735 & & -2.32 & 0.020 \\
\hline Conviction & 0.01994 & & 32.61 & 0.000 \\
\hline $\mathrm{F}_{\text {model }}$ & 281.23 & & & $\mathrm{p}$-value $=0.000$ \\
\hline $\mathrm{R}^{2}$ (adjusted $\mathrm{R}^{2}$ ) & & & $56.9 \%(56.7 \%)$ & \\
\hline
\end{tabular}

The regression equation is:

Intention $=1.21+0.0471$ (Country) $-0.158($ Work Experience $)-0.0868($ Self-employed $)+0.650($ Conviction $)$

Dependent variable: Intention

From the second section, the "Motivation" construct was examined to determine its effect on the "Conviction" construct. The results show that the proposed relations with the "Conviction" construct is valid and was able to explain $45.8 \%$ of the variability of the construct, and the independent construct "Motivation" is significantly important (Hypothesis 3).

From the third section, which is shown from Table-5, the "Perceived situation" construct was developed to determine its effect on the "Motivation" construct. The results show that students who have positive perception of the external environment are more likely to be motivated to enlist or participate in studying entrepreneurship studies (Hypothesis 4). The results from Table-5 show that the proposed relations with the "Motivation" construct is valid and was able to explain $30.2 \%$ of the variability of the construct, and all independent variables are significantly important.

Table 5. Multivariable regression analysis to predict motivation

\begin{tabular}{|c|c|c|c|}
\hline Predictor Variable & Standard Coefficient (SE) & t-value & p-value \\
\hline Perceived Market Situation & 0.02420 & 7.40 & 0.000 \\
\hline $\begin{array}{ll}\text { Perceived } & \text { Financial } \\
\text { Situation } & \end{array}$ & 0.03051 & 4.37 & 0.000 \\
\hline Perceived Social Situation & 0.02621 & 12.81 & 0.000 \\
\hline $\begin{array}{l}\text { Perceived University } \\
\text { Education }\end{array}$ & 0.03245 & 3.21 & 0.001 \\
\hline $\begin{array}{l}\mathrm{F}_{\text {model }} \\
\mathrm{R}^{2}\left(\text { adjusted } \mathrm{R}^{2}\right)\end{array}$ & 93.38 & $\%(30.2 \%$ & $\mathrm{p}$-value $=0.000$ \\
\hline
\end{tabular}

The regression equation is:

$$
\text { Motivation }=1.20+0.179(\text { Market })+0.133(\text { Financial })+0.336(\text { Social })+0.104(\text { University })
$$

Dependent variable: Motivation

Also, ANOVA was used to test the fifth hypothesis (there are no differences of Intention among students from different Arab countries). The result from Table 6 shows that there are differences of the "Intention" construct levels among students from different Arab countries as evident by the p-value. 
Table 6. One-way ANOVA: intention versus country

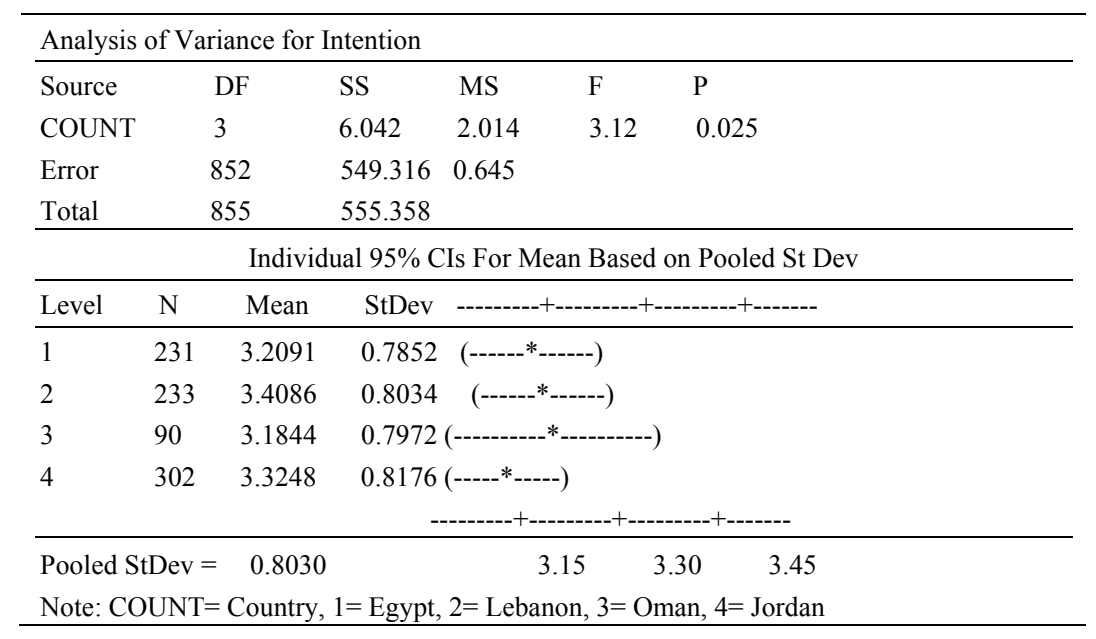

Table 7 shows a summary of hypotheses findings. All hypotheses are accepted except hypotheses number 1 (H1).

Table 7. Summary of hypotheses findings

\begin{tabular}{lll}
\hline No. & Hypotheses & Findings \\
\hline H1 & $\begin{array}{l}\text { Entrepreneurial intention of university students is positively related to conviction } \\
\text { to start a business }\end{array}$ & Accept \\
H2 & $\begin{array}{l}\text { The remaining psychometric variables (family history, self-employed, country) } \\
\text { have effects on Entrepreneurial intention of university students }\end{array}$ & Accept \\
H3 & $\begin{array}{l}\text { Students who are motivated to study entrepreneurship studies are more likely to } \\
\text { have higher convictions to start their own business } \\
\text { Students who have positive perception of the external environment are more likely }\end{array}$ & Accept \\
H4 & $\begin{array}{l}\text { Accept } \\
\text { to be motivated to enlist or participate in studying entrepreneurship studies } \\
\text { The determinants of Entrepreneurial intention are the same between students in } \\
\text { selected Arab countries }\end{array}$ & Reject \\
& & \\
\hline
\end{tabular}

\section{Conclusions}

Some limitations must be acknowledged here. First, the cross-sectional nature of a survey design limits the inferences drawn about causality between the constructs of interest, while this shortcoming presents opportunities for future research to investigate; this approach is consistent with prior research in this area. Second, a more comprehensive effort at developing multidimensional scales of the proposed constructs is an area worthy of future research. Finally, the overall proposed framework is limited to the inclusion of constructs driven by parsimony, while the model fit results supports the appropriateness of the proposed constructs and explains adequate variances, but potentially more variables could be included to further explain how intention to be entrepreneurial could be motivated.

The findings have important implications for governmental policy makers and university administrators. First, governmental policies could be enacted in order to create a climate that motivates individuals to be entrepreneurial. The policies should be targeted to support the creation of microfinance sector in a country. Second, ease of regulations, laws, and procedures to start a business. Also, university administrators are concerned with the findings of this study in the following ways. First, a university curriculum could be designed to emphasize the importance to be entrepreneurial, and to provide the necessary skills and tools to support such a desire of its students. Second, a university could promote entrepreneurship throughout its campus via conferences and workshops. Third, a university could establish on-campus incubators and entrepreneurial center unit that is responsible for providing adequate training and facilities to support new business starters' for its students and the community.

This study extends the entrepreneurial intention literature by conceptualizing and proposing a framework that could predict the intention among university students. The findings stress the role that a university could play at 
motivating its students to be entrepreneurial and the governmental role in creating a perceived climate that encourages entrepreneurship. Overall, this study advances the understanding of how intention among university students can be influenced and pinpoints to different drivers that could be under the control a university and the government. The study encourages future research efforts to extend the findings and offer further insights into this important topic.

\section{References}

Ajzen, I. (1991). The Theory of Planned Behaviour. Organizational Behaviour and Human Decision Processes, 50(2), 179-211. http://dx.doi.org/10.1016/0749-5978(91)90020-T

Ang, S. H., \& Hong, D. G. P. (2000). Entrepreneurial spirit among East Asian Chinese. Thunderbird International Business Review, 42(3), 285-309. http://dx.doi.org/10.1002/1520-6874(200005/06)42:3<285::AID-TIE2>3.0.CO;2-5

Bird, B. (1988). Implementing entrepreneurial ideas: the case for intentions. Academy of Management Review, 13(3), 442-453.

Bird, B. (1993). Demographic Approaches to Entrepreneurship: the Role of Experience and Background. Advances in Entrepreneurship, Firm Emergence, and Growth, 1, 11-48.

Boyd, N. G., \& Vozikis, G. S. (1994). The influence of self-efficacy on the development of entrepreneurial intentions and actions. Entrepreneurship Theory and Practice, 18, 64-77.

Devonish, D., Alleyne, P., Charles-Soverall, W., Young Marshall, A., \& Pounder, P. (2010). Explaining entrepreneurial intentions in the Caribbean. International Journal of Entrepreneurial Behavior and Research, 16(2), 149-171. http://dx.doi.org/10.1108/13552551011027020

Douglas, E. J., \& Shepherd, D. A. (2002). Self-employment as a career choice: Attitudes, entrepreneurial intentions, and utility maximization. Entrepreneurship: Theory and Practice, 26(3), 81-90.

Engle, R., Dimitriadi, N., Gavidia, J., Schlaegel, C., Delanoe, S., Alvarado, I., He, X., Baume, S., \& Wolff, B. (2010). Entrepreneurial intent: a 12-country evaluation of Ajzen's model of planned behavior. International Journal of Entrepreneurial Behaviour and Research, 16(1), 35-57. http://dx.doi.org/10.1108/13552551011020063

Etzkowitz, H., Webster, A., Gebhardt, C., \& Terra, B. R. C. (2000). The future of the university and the university of the future: evolution of ivory tower to entrepreneurial paradigm. Research Policy, 29(2), 313-30. http://dx.doi.org/10.1016/S0048-7333(99)00069-4

Gibb, A. (1996). Entrepreneurship and small business management: can we afford to neglect them in the twenty-first century business school? British Journal of Management, 7(4), 309-321. http://dx.doi.org/10.1111/j.1467-8551.1996.tb00121.x

Gird, A., \& Bagraim, J. J. (2008). The theory of planned behavior as predictor of entrepreneurial intent amongst final-year university students. South African Journal of Psychology, 38(4), 711-24. http://dx.doi.org/10.1177/008124630803800410

Good, T. L., \& Brophy, J. E. (1990). Educational Psychology. A Realistic Approach, Longman, New York, NY.

Hambleton, R. K. (1994). Guidelines for adapting educational and psychological tests: a progress report. European Journal of Psychological Assessment, 10(3), 229-244.

Helm-Stevens, R., \& Griego, O. (2009). A path analysis model of intrinsic and extrinsic academic motivation engagement in service learning. Review of Business Research, 9(1), 99-103.

Hytti, U., Stenholm, P., Heinonen, J., \& Seikkula-Leino, J. (2010). Perceived learning outcomes in entrepreneurship education: The impact of student motivation and team behavior. Education +Training, 52(8/9), 587-606. http://dx.doi.org/10.1108/00400911011088935

Iakovleva, T., Kolvereid, L., \& Stephan, U. (2011). Entrepreneurial intentions in developing and developed countries. Education + Training, 53(5), 353-370. http://dx.doi.org/10.1108/00400911111147686

Johannisson, B., Handstro"m, H., \& Rosenberg, J. (1998). University training for entrepreneurship: an action frame of reference. European Journal of Engineering Education, 23(4), 477-496. http://dx.doi.org/10.1080/03043799808923526

Jones, P., Jones, A., Packham, G., \& Miller, C. (2008). Student attitudes towards enterprise education in Poland: a positive impact. Education + Training, 50(7), 597-614. http://dx.doi.org/10.1108/00400910810909054 
Krueger, N. (1994). Strategic Optimism: Antecedents of Perceived Probabilities of New Venture Success. paper presented at the Academy of Management meeting, BPS Division.

Krueger, N. F., Reilly, M. D., \& Carsrud, A. L. (2000). Competing models of entrepreneurial intentions. Journal of Business Venturing, 15(5/6), 411-432. http://dx.doi.org/10.1016/S0883-9026(98)00033-0

Liña'n, F., \& Chen, Y. W. (2009). Development and cross-cultural application of a specific instrument to measure entrepreneurial intentions. Entrepreneurship Theory and Practice, 33(3), 593-617. http://dx.doi.org/10.1111/j.1540-6520.2009.00318.x

Liña'n, F., Rodríguez-Cohard, J., \& Rueda-Cantuche, J. (2005). Factors affecting entrepreneurial intention levels. 45th Congress of the European Regional Science Association, Amsterdam, 23-27 august.

Lu" thje, C., \& Franke, N. (2003). The 'making' of an entrepreneur: testing a model of entrepreneurial intent among engineering students at MIT. R\&D Management, 33(2), 135-47.

Ma'rio, F., Heiko, H., \& Arndt, L. (2010). Students' entrepreneurial intentions: an inter-regional comparison. Education \& Training, 52(4), 260-275. http://dx.doi.org/10.1108/00400911011050945

Matlay, H. (2006). Entrepreneurship education: more questions than answers? Education +Training, 48(5), 293-295.

Moriano, J. A., Gorgievski, M., Laguna, M., Stephan, U., \& Zarafshani, K. (2011). A cross-cultural approach to understanding entrepreneurial intention. Journal of Career Development (in press).

Nabi, G., \& Liña'n, F. (2011). Graduate entrepreneurship in the developing world: intentions, education and development. Education + Training, 53(5), 325-334. http://dx.doi.org/10.1108/00400911111147668

Nabi, G., Holden, R., \& Walmsley, A. (2010) Entrepreneurial intentions among students: towards a re-focused research agenda. Journal of Small Business and Enterprise Development, 17(4), 537-551. http://dx.doi.org/10.1108/14626001011088714

Nunnally, J. (1978). Psychometric Theory (2nd ed.). McGraw-Hill, New York, NY.

Peterman, N., \& Kennedy, J. (2003). Enterprise education: influencing students' perceptions of entrepreneurship. Entrepreneurship Theory and Practice, 28(2), 129-44. http://dx.doi.org/10.1046/j.1540-6520.2003.00035.x

Reynolds, P. D. (1991). Sociology and entrepreneurship: concepts and contributions. Entrepreneurship Theory and Practice, 16(2), 47-70.

Reynolds, P. D., Camp, S. M., Bygrave, W. D., Autio, E., \& Hay, M. (2001). Global Entrepreneurship Monitor: 2001 Executive Report. Kansas City, MO: Kauffman Center for Entrepreneurial Leadership.

Schwarz, E., Wdowiak, M., Almer-Jarz, D., \& Breitenecker, R. (2009). The effects of attitudes and perceived environment conditions on students' entrepreneurial intent: An Austrian perspective. Education +Training, 51(4), 272-291.

Shapero, A., \& Sokol, L. (1982). The social dimension of entrepreneurship. In Kent, C. A., Sexton, D. L., \& Vesper, K. H. (Eds.), Encyclopedia of Entrepreneurship (pp. 72-90). Prentice-Hall, Englewood Cliffs, NJ.

Stephen, F. H., Urbano, D., \& Hemmen, S. V. (2005). The impact of institutions on entrepreneurial activity. Managerial and Decision Economics, 26(7), 413-9. http://dx.doi.org/10.1002/mde.1254

Storey, D. J. (1994). Understanding the small business sector. Routledge, London.

Thompson, E. R. (2009). Individual entrepreneurial intent: construct clarification and development of an internationally reliable metric. Entrepreneurship Theory and Practice, 33(3), 669-694. http://dx.doi.org/10.1111/j.1540-6520.2009.00321.x

Thurik, A. R. (2009). Entreprenomics: entrepreneurship, economic growth and policy. In Acs, Z. J., Audretsch, D. B., \& Strom, R. (Eds.), Entrepreneurship, Growth and Public Policy (pp. 219-249). Cambridge: Cambridge University Press. http://dx.doi.org/10.1017/CBO9780511805950.011

Turker, D., \& Selcuk, S. (2009). Which factors affect entrepreneurial intention of university students? Journal of European Industrial Training, 33(2), 142-159. http://dx.doi.org/10.1108/03090590910939049

Vaillant, Y., \& Lafuente, E. (2007). Do different institutional frameworks condition the influence of local fear of failure and entrepreneurial examples over entrepreneurial activity? Entrepreneurship and Regional Development, 19(4), 313-337. http://dx.doi.org/10.1080/08985620701440007

Veciana, J. M., Aponte, M., \& Urbano, D. (2000). University student's attitudes towards entrepreneurship: a 
two-country comparison. Entrepreneurship Summit 2000, Puerto Rico, 28-30 January.

Wang, C. K., \& Wong, P. K. (2004). Entrepreneurial interest of university students in Singapore. Technovation, 24(2), 163-72. http://dx.doi.org/10.1016/S0166-4972(02)00016-0

$\mathrm{Wu}, \mathrm{S} ., \& \mathrm{Wu}, \mathrm{L}$. (2008). The impact of higher education on entrepreneurial intentions of university students in China. Journal of Small Business and Enterprise Development, 15(4), 752-774. http://dx.doi.org/10.1108/14626000810917843

\section{$\underline{\text { Appendix-A }}$}

1.

2.

3.

a.

b.

4.

a.

b.

5.

a.

b.

i.

1.

2.

6.

a.

b.

7.

\section{Country:}

Name of University:

Type of University

Private

Government

Sex:

Male

Female

Do you work?

Yes

No

If Yes: Are you self-employed?

Yes

No

Does any of your immediate family members self-employed?

Yes

No

Major:

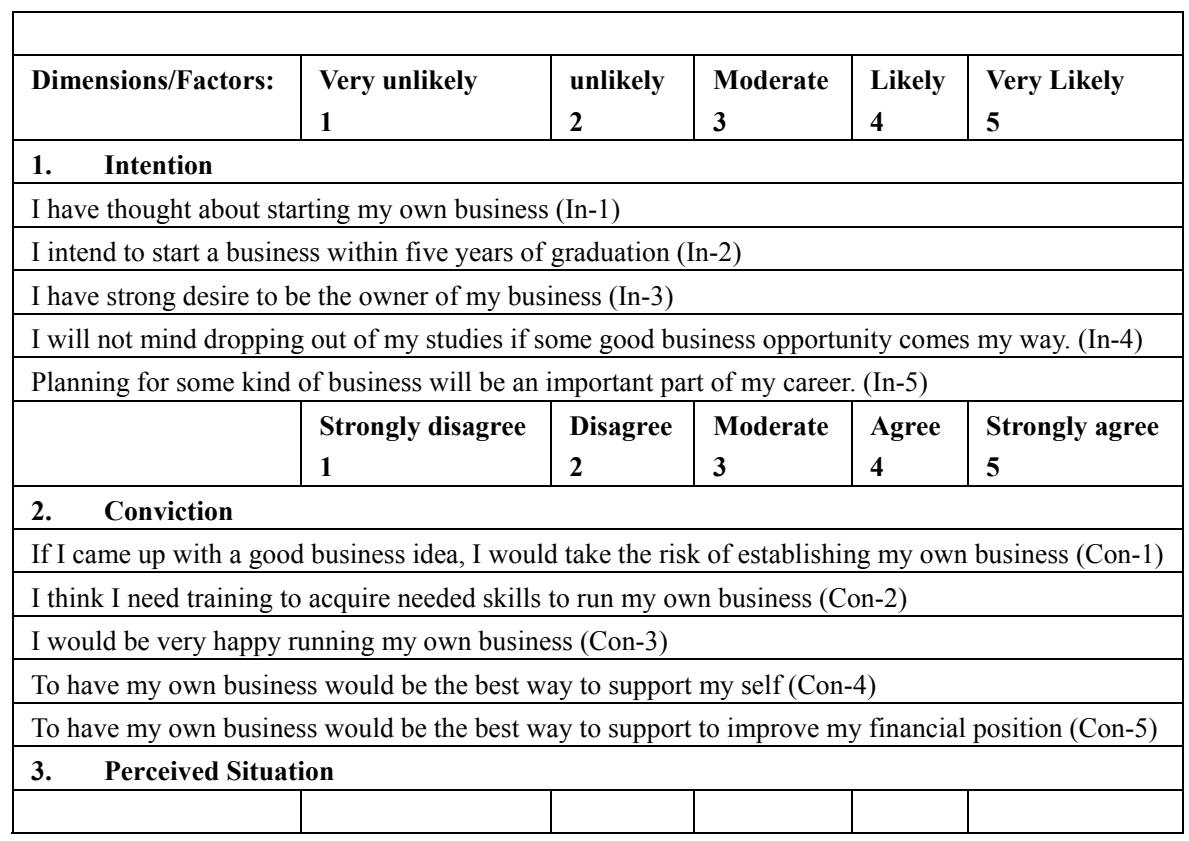




\begin{tabular}{|c|c|c|c|c|c|c|c|}
\hline & 3.1 Market & $\begin{array}{l}\text { Strongly disagree } \\
1\end{array}$ & $\begin{array}{l}\text { Disa: } \\
2\end{array}$ & $\begin{array}{l}\text { Moderat } \\
3\end{array}$ & $\begin{array}{l}\text { Agree } \\
4\end{array}$ & $\begin{array}{l}\text { Strongly a } \\
5\end{array}$ & \\
\hline & There are hig & ve pressures to start $u$ & a busi & s (PRMK-1) & & & \\
\hline & Most busine & been realized before & (PRMK & & & & \\
\hline & There are no & hess/entrepreneurial o & portun & s in our count & $y($ PRMK-3) & & \\
\hline & Our econom & hany opportunities fo & startup & siness (PRMK & & & \\
\hline & & $\begin{array}{l}\text { Strongly dis } \\
1\end{array}$ & gree & $\begin{array}{l}\text { Disagree } \\
2\end{array}$ & $\begin{array}{l}\text { Moderate } \\
\mathbf{3}\end{array}$ & $\begin{array}{l}\text { Agree } \\
4\end{array}$ & $\begin{array}{l}\text { Strongly agree } \\
5\end{array}$ \\
\hline & & & & & & & \\
\hline & places to ventu & ther than banks in my & country & RFI-1) & & & \\
\hline & $m$ banks is qui & or entrepreneurs in $\mathrm{m}$ & count & PRFI-2) & & & \\
\hline & & $\begin{array}{l}\text { Strongly dis } \\
1\end{array}$ & gree & $\begin{array}{l}\text { Disagree } \\
2\end{array}$ & $\begin{array}{l}\text { Moderate } \\
3\end{array}$ & $\begin{array}{l}\text { Agree } \\
4 \\
\end{array}$ & $\begin{array}{l}\text { Strongly agree } \\
5\end{array}$ \\
\hline & t Policy & & & & & & \\
\hline & have sufficien & ubsidies for startup b & siness & GV-1) & & & \\
\hline & have qualifiec & and support for new & usiness & (PRGV-2) & & & \\
\hline & s (rules and re & re adverse to running & busin & (PRGV-3) & & & \\
\hline & and policies fo & new business are un & ear $(\mathrm{PI}$ & $\mathrm{V}-4)$ & & & \\
\hline & support and $\mathrm{e}$ & trepreneurs efforts (I & RGV-5 & & & & \\
\hline & & $\begin{array}{l}\text { Strongly dis } \\
1\end{array}$ & gree & $\begin{array}{l}\text { Disagree } \\
2\end{array}$ & $\begin{array}{l}\text { Moderate } \\
\mathbf{3} \\
\end{array}$ & $\begin{array}{l}\text { Agree } \\
4 \\
\end{array}$ & $\begin{array}{l}\text { Strongly agree } \\
5\end{array}$ \\
\hline & & & & & & & \\
\hline & e highly respe & ociety (PRSC-1) & & & & & \\
\hline & ourages and su & reneurs efforts (PRSC & & & & & \\
\hline & & $\begin{array}{l}\text { Strongly dis } \\
1\end{array}$ & gree & $\begin{array}{l}\text { Disagree } \\
2\end{array}$ & $\begin{array}{l}\text { Moderate } \\
\mathbf{3} \\
\end{array}$ & $\begin{array}{l}\text { Agree } \\
4 \\
\end{array}$ & $\begin{array}{l}\text { Strongly agree } \\
5\end{array}$ \\
\hline & ducation & & & & & & \\
\hline & at my univers & me with the knowlec & ge requ & do startup a $n$ & w business & PRUV-1) & \\
\hline & my university & me to develop creati & e ideas & $r$ being an entr & preneur (PR & UV-2) & \\
\hline & evelops my ent & I skills and abilities (I & RUV-3 & & & & \\
\hline & tively promot & ss of founding a new & usines & RUV-4) & & & \\
\hline & rovides a stron & f new venture invest & $\mathrm{s}$ (PRL & & & & \\
\hline & ny university f & ial and leadership ski & Is need & to startup new & usiness (PR & UV-6) & \\
\hline & at my univers & me well for self-emp & oymen & RUV-7) & & & \\
\hline & ny university $h$ & reate a business plan & nd a br & ess concept (I & RUV-8) & & \\
\hline & ny university h & Iderstand the type of $i$ & sues th & confront an en & epreneur in & taking an ide & to market (PRUV-9) \\
\hline & ny university $p$ & with the necessary te & hnique & $\mathrm{r}$ finding out $\mathrm{v}$ & hat the mark & et wants (PR & $\mathrm{V}-10)$ \\
\hline & ny university e & o know how to legall & financ & new business & oncept (PRL & $\mathrm{JV}-11)$ & \\
\hline & ranges for con & workshops on entrep & neursh & (PRUV-12) & & & \\
\hline & romotes an aw & Atrepreneurship as a p & sssible & eer choice $(\mathrm{PR}$ & UV-13) & & \\
\hline & ings students & ith the network neede & to sta & new business & PRUV-14) & & \\
\hline & ings entrepren & nts as speakers to sen & inars $(\mathrm{I}$ & JV-15) & & & \\
\hline & rovides studen & nancial means neede & to star & new business & PRUV-16) & & \\
\hline & & $\begin{array}{l}\text { Strongly dis } \\
1\end{array}$ & gree & $\begin{array}{l}\text { Disagree } \\
2\end{array}$ & $\begin{array}{l}\text { Moderate } \\
\mathbf{3} \\
\end{array}$ & $\begin{array}{l}\text { Agree } \\
4 \\
\end{array}$ & $\begin{array}{l}\text { Strongly agree } \\
5\end{array}$ \\
\hline & tudy Entrepre & & & & & & \\
\hline & n studying ent & $\mathrm{p}(\mathrm{MENT}-1)$ & & & & & \\
\hline & trepreneurship & ould not have to (ME & $\mathrm{JT}-2)$ & & & & \\
\hline & eneurship is $\mathrm{n}$ & ince one day I may be & an entr & eneur myself & MENT-3) & & \\
\hline & eneurship is ir & me, since it helps me & to bett & nderstand entr & preneurship & and entrepre & urs (MENT-4) \\
\hline & trepreneurship & ant that I will learn & neces & y knowledge a & d skills ne & led in entrep & neurship (MENT-5)। \\
\hline & ntrenrene & ble to familiariz & & & & & \\
\hline
\end{tabular}




\section{General Information:}

I. Does your university have an incubator on campus?

a. Yes

b. $\quad$ No

II. Define what is meant by entrepreneurship, and what does it take to be an entrepreneur?

\section{Copyrights}

Copyright for this article is retained by the author(s), with first publication rights granted to the journal.

This is an open-access article distributed under the terms and conditions of the Creative Commons Attribution license (http://creativecommons.org/licenses/by/3.0/). 